\title{
Zorik I. \\ NUMERICAL SIMULATION OF THE OUTFLOW OF TWO PHASE FLOW FROM DETONATION UNIT BARREL
}

Об'єктом дослідження є нанесення детонащійнх покриттів із застосуванням дешевих $і$ безпечних енергоносіїв без зниження якісних характеристик покриттів. Одним із суттєвих недоліків детонаційному-газового методу, з точки зору безпеки та вартості, є широке використання ацетилен-кисневих сумішей. В деякій мірі застосування пропан-бутанових сумішей вирішує проблему, проте знижуються енергетичні параметри процесу, що обумовлює пошук компромісного рішення - метилацетилен-алленової фракщї (МАФ). Цей енергоносій займає проміжне положення за енергетичними характеристиками і при цьому є стабільним і безпечним. Застосування різних енергоносіїв вимагає детальної інформації про динаміку поведінки продуктів детонації та частинок, що напилюються в стовбурі детонаційної установки. В ході досліджень вирішена задача про розвиток дефлаграціонного горіння, переходу в детонащію всередині технологічного каналу установки та руху фронту детоначійної та ударної хвилі на основі рівнянь Нав'є-Стокса з двошаровою моделлю турбулентності Ментера. Для розрахунку багатофазних потоків використовувалася модель об'єму рідини (VOF), яка передбачає, що дві рідини (або фази) або більш не змішуються та не проникають одна в одну. Наведено результати чисельного моделювання процесу витікання продуктів детонацї зі стовбура детонащійної установки, а також процесу теплообміну між продуктами згоряння та частинками порошку. Визначено швидкості та температури частинок оксиду алюмінію для різних співвідношень МАФ/кисень на виході з технологічного каналу та перед підкладкою. Проведено порівняння результатів чисельного моделювання з даними експериментальних досліджень. Показано, що використана модель адекватно описує процес теплообміну. В результаті проведених досліджень обтрунтовано застосування в якості енергоносія МАФ без зниження якості покриттів з оксидної кераміки. Розроблена математична модель придатна для моделювання процесу з будь-яких поєднань газових компонентів, здатних детонувати.

Ключові слова: Әетонаційне напилювання, газотермічні покриття, теплообмін в двофазному потоці, математичне моделювання процесів детонації.

\section{Introduction}

Detonation spraying was originally implemented by the American company Union Carbide in the 1950s, which continues to create new patented developments in this area [1,2]. It has been shown that acetylene-oxygen and other mixtures of hydrocarbon fuels with an oxidizing agent capable of detonating, for example, methane or propane-butane can be used as energy carriers. In this case, the length of the zone of transition of the combustion process to detonation increases, and the energy characteristics significantly differ from the acetylene-oxygen mixtures for the worse.

Currently, MAF (methylacetylene-allene fraction) is increasingly used in gas welding and metal cutting instead of acetylene. Since it is cheaper and safer and is a mixture of methylacetylene (propine) and allene (propadiene), stabilized for safety reasons with propane, propylene, butane or other hydrocarbons in various combinations. However, in the literature, the detonation parameters of composite hydrocarbon fuels are hardly considered. In detonation spraying, the mechanism of formation of strongly coupled coatings is equally determined by the intensity of both thermal and mechanical activation of the surface layers of the materials being joined. The development of optimal technological processes for spraying should be carried out with the choice of a rational ratio between the velocity and temperature of the sprayed particles. Improving the operational properties of the most loaded parts of aircraft engines is possible using several approaches, such as the development of new materials, the improvement of manufacturing methods, and the use of new technological processes. As well as the development of methods for surface hardening of parts, the use of various protective coatings. Since the operational characteristics of parts and components of aircraft engines significantly depend on the quality characteristics of the surface and the surface layer, the use of various types of thermal spray coatings is relevant. Thus, the object of research is the application of detonation coatings using cheap and safe energy sources without reducing the quality characteristics of the coatings. The aim of research is to establish the laws of formation of the energy parameters of the applied powders (velocity, temperature), affecting the physical and mechanical properties of the surface layer, in particular adhesive and cohesive strength. 


\section{Methods of research}

As research methods, numerical modeling of the coating process and experiments is used.

An analysis of studies of two-phase gas flows with particles shows that in the last few decades this issue has periodically been of constant interest. It should be noted that most of the calculations of carrier gas flows are based on a system of Navier-Stokes equations averaged by the Reynolds - RANS (Reynolds Averaged Navier-Stokes system) [3], with one or another model of turbulence. Direct numerical simulation - DNS (Direct Numerical Simulation) involves solving the complete non-stationary Navier-Stokes equations and the continuity equation. Thus, no additional modeling is required and all effects inherent in the flow are taken into account. The difficulties of the DNS are limited computer resources, even at present. Recently, works have appeared that use methods such as: large eddy simulation - LES (Large Eddy Simulation), detached eddy simulation - DES (Detached Eddy Simulation) and their modifications [4, 5], which require significant computational resources.

In addition to DES and LES, there are many systems of Navier-Stokes equations averaged by Reynolds, which have both advantages (relatively low requirements for computing resources) and significant disadvantages a limited scope. One of the common $k-\omega$ type models proposed by Wilcox [6] gives a good description of the $k-\omega$ model of near-wall flows with separation of the boundary layer.

To simulate a wide range of turbulent flows, the most common at present are $k-\varepsilon$ models due to sufficiently good convergence and accuracy. However, they have a limited scope, since they poorly describe flows with a strong flow curvature, swirl flows, separation flows, secondary flows, and near-wall flows. The advantages of $k-\varepsilon$ models in describing flows and $k-\omega$ in describing wall functions were realized in the two-layer Menter's model [7]. For this, the $k-\varepsilon$ model was written in terms of $k$ and $\omega$, and then the weight function $F_{1}$ was introduced into the obtained model equations, which ensures a smooth transition from the $k-\omega$ model in the near-wall region to the $k-\varepsilon$ model far from the wall. The function $F_{1}$ is selected in such a way as to be equal to zero at the upper boundary of the boundary layer and tends to unity when approaching the wall. Also, in the Menter model, the standard relationship between the kinetic energies $k$, the dissipation rate $\varepsilon$, and the turbulent viscosity $t_{\mu}$ is modified. For communication, a special limiting function is introduced - SST (shear stress transport) - shear stress transfer.

The process of burning gaseous fuel mixtures with a transition from a deflagration to a detonation mode of combustion, with the determination of temperature fields, velocities, concentrations of components, taking into account the kinetics of the process, is quite complicated for both experimental research and mathematical modeling.
According to the manufacturer [8], MAF is a mixture of the components shown in Table 1.

Kinetics is calculated by the global mechanism. For this, the following gross hydrocarbon combustion equations are pleasant: $\mathrm{C}_{3} \mathrm{H}_{4}+4 \mathrm{O}_{2}=2 \mathrm{H}_{2} \mathrm{O}+3 \mathrm{CO}_{2}, \mathrm{C}_{3} \mathrm{H}_{8}+5 \mathrm{O}_{2}=$ $=3 \mathrm{CO}_{2}+4 \mathrm{H}_{2} \mathrm{O}, 2 \mathrm{C}_{3} \mathrm{H}_{6}+9 \mathrm{O}_{2}=6 \mathrm{CO}_{2}+6 \mathrm{H}_{2} \mathrm{O}, \mathrm{C}_{4} \mathrm{H}_{10}+\mathrm{O}_{2}=$ $=\mathrm{CH}_{3} \mathrm{COOH}+\mathrm{H}_{2} \mathrm{O}$.

To determine the stoichiometric ratio of MAF/oxygen, it is necessary to calculate the molar masses for each of the components of the gross reactions. Thus, the stoichiometric ratio: $0.316=41.55 / 131.43$, and the equimolar ratio: $1.298=41.55 / 31.99$.

Table 1

composition of the methylacetylene-allen fraction (MAF)

\begin{tabular}{|c|c|c|c|c|c|}
\hline $\begin{array}{l}\text { nemical } \\
\text { ormula }\end{array}$ & $\begin{array}{c}\text { Volume } \\
\text { fraction, \% }\end{array}$ & $\begin{array}{c}\text { Average } \\
\text { value }\end{array}$ & $\begin{array}{c}\text { Molar mass } \\
\text { of hydrocar- } \\
\text { bon, g/mol }\end{array}$ & $\begin{array}{c}\text { Component/ } \\
\text { Oxygen } \\
\text { Weight }\end{array}$ & $\begin{array}{l}\text { Including } \\
\% \text { content in } \\
\text { MAF }\end{array}$ \\
\hline $\begin{array}{l}\mathrm{C}_{3} \mathrm{H}_{4} \\
\left.\mathrm{H}_{3} \mathrm{C} \equiv \mathrm{CH}\right)\end{array}$ & $38.0-47.1$ & \multirow{2}{*}{72.5} & \multirow{2}{*}{40.06386} & \multirow{2}{*}{$\begin{array}{c}40.06386 / \\
127.9952\end{array}$} & \multirow{2}{*}{$\begin{array}{c}29.0462985 / \\
92.79652\end{array}$} \\
\hline $\begin{array}{l}\mathrm{C}_{3} \mathrm{H}_{4} \\
\left.=\complement=\mathrm{CH}_{2}\right)\end{array}$ & $27.8-37.0$ & & & & \\
\hline $\mathrm{C}_{3} \mathrm{H}_{8}$ & $14.6-24.2$ & 18.5 & 44.09562 & $\begin{array}{c}44.09562 / \\
159.994 \\
\end{array}$ & $\begin{array}{c}8.1576897 / \\
29.59889\end{array}$ \\
\hline $\mathrm{C}_{3} \mathrm{H}_{6}$ & $0.8-10.4$ & 5.5 & 42.07974 & $\begin{array}{c}42.07974 / \\
143.9946 \\
\end{array}$ & $\begin{array}{c}2.3143857 / \\
7.919703\end{array}$ \\
\hline $\mathrm{C}_{4} \mathrm{H}_{10}$ & $1.0-6.0$ & 3.5 & 58.1222 & $\begin{array}{l}58.1222 / \\
31.9988 \\
\end{array}$ & $\begin{array}{c}2.034277 / \\
1.119958 \\
\end{array}$ \\
\hline- & 0.5 & - & - & - & - \\
\hline
\end{tabular}

The computational domain is a barrel with a length of $1700 \mathrm{~mm}$ and a diameter of $24 \mathrm{~mm}$, partially filled with a gas mixture capable of detonating at initial pressures, density and temperature. A significant increase in the size of the computational domain, with gas parameters equal to atmospheric pressure and temperature, takes place at the barrel section.

Thus, the nature of the outflow to ensure conditions close to the actual parameters of the outflow of detonation products. At a distance of $120 \mathrm{~mm}$ there is a flat barrier imitating a substrate. To reduce the calculation time, the model, since it is axisymmetric, is presented in equivalent two-dimensional form.

\section{Research results and discussion}

As a result of the calculations in the ANSYS Fluent medium, temperature, velocity, and pressure values were obtained over time, depending on the fuel content in the explosive mixture (Fig. 1).

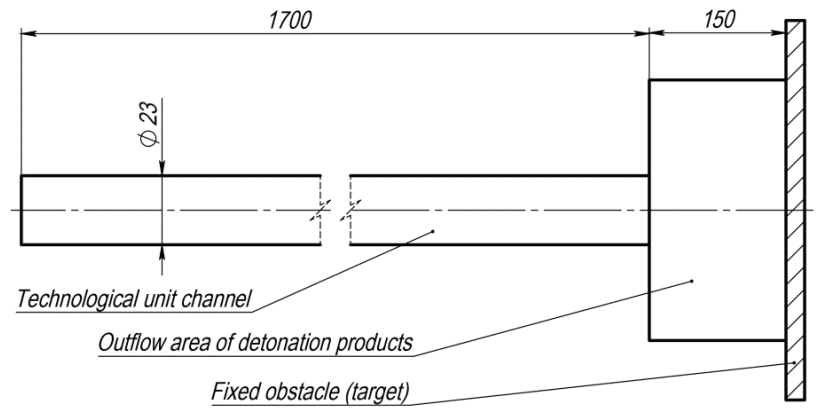

Fig. 1. The calculated scheme of the outflow of detonation products from the barrel of the detonation unit 
The velocities and temperatures of the powder materials are calculated and shown at characteristic points - on a section of the barrel and directly in front of the target. The outflow of detonation products after the passage of shock and detonation waves, at time $t=0.036 \mathrm{~s}$ after initiation, can be qualitatively analyzed in Fig. 2-4. An example of calculation is given for the stoichiometric ratio of the detonating mixture of MAF-oxygen.

The distribution of gas-dynamic parameters is shown in Fig. 5-7.

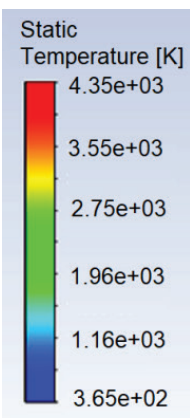

Fig. 2. Distribution of temperature fields along the unit barrel

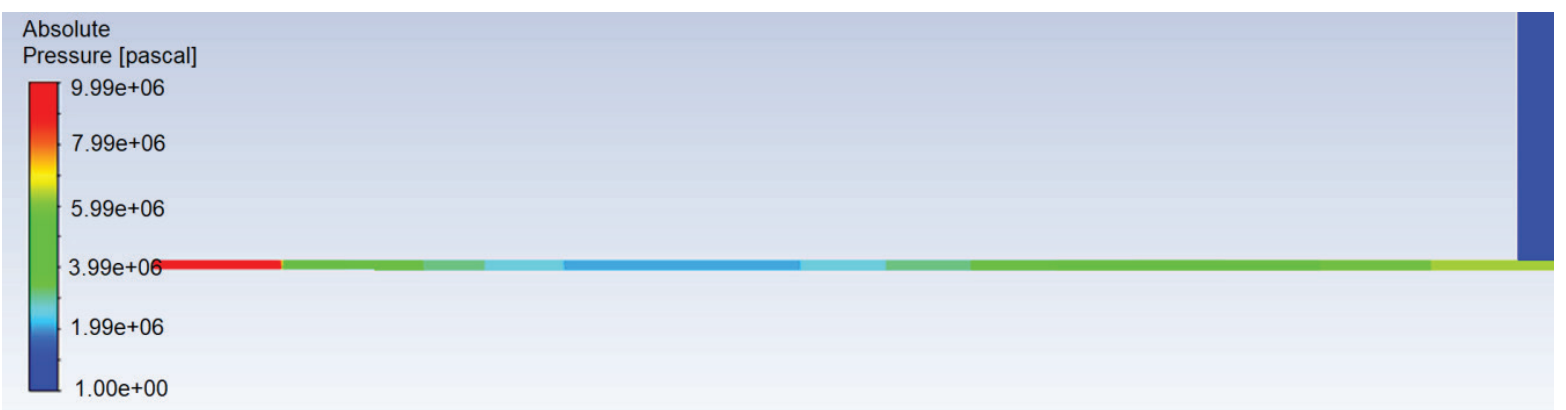

Fig. 3. Distribution of pressure fields along the unit barrel

$$
\begin{aligned}
& \text { Velicity } \\
& \text { Magnitude }[\mathrm{m} / \mathrm{s}] \\
& 4.44 \mathrm{e}+03 \\
& 3.55 \mathrm{e}+03 \\
& 2.66 \mathrm{e}+03 \\
& 1.77 \mathrm{e}+03 \\
& 8.87 \mathrm{e}+02 \\
& 0.00 \mathrm{e}+00
\end{aligned}
$$

Fig. 4. Distribution of velocity fields along the unit barrel
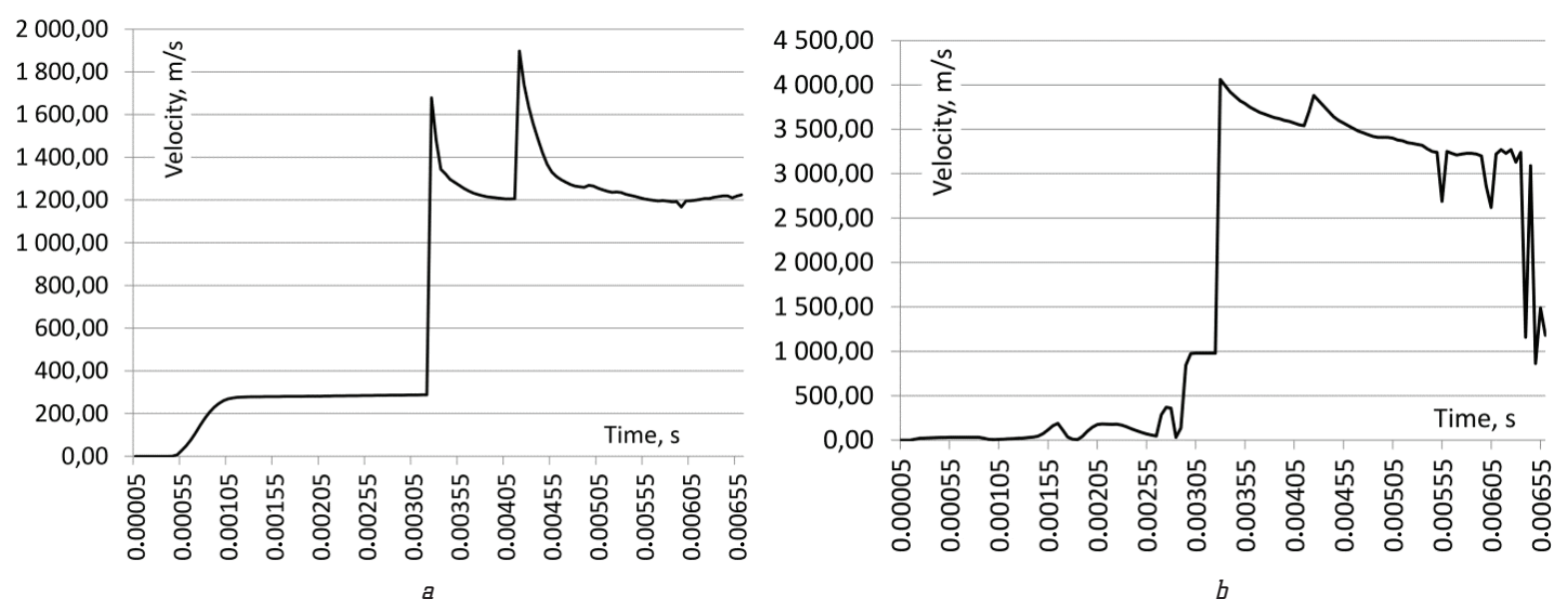

Fig. 5. The parameters of the outflow velocity of detonation products: $a$ - barrel section; $b-$ at the obstacle 

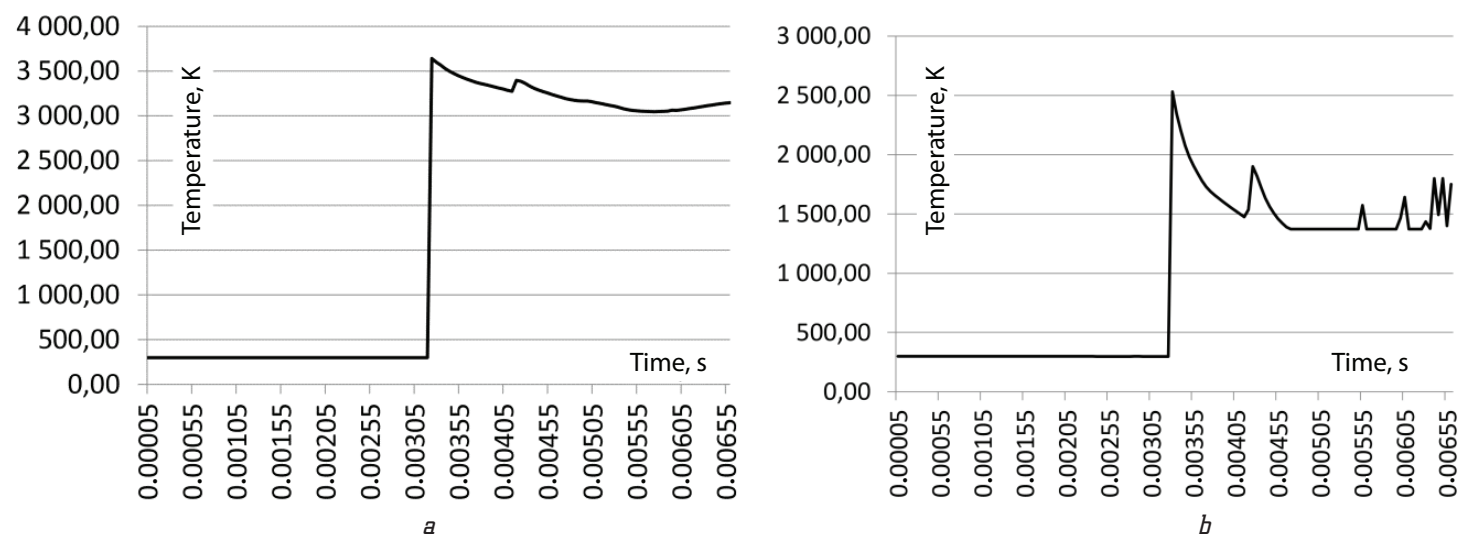

Fig. 6. Temperature parameters of detonation products: $a$ - barrel section; $b$ - at the obstacle

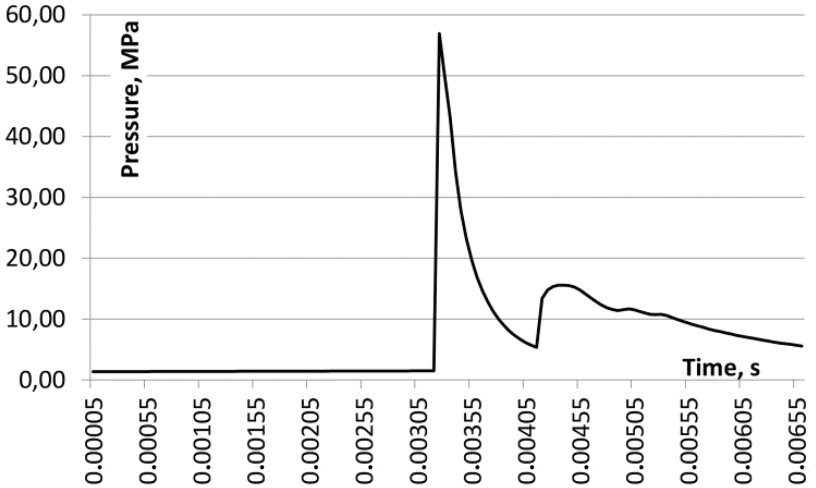

Fig. 7. Pressure parameters at the detonation unit barrel section

To determine the velocity and temperature of the particles of the applied powder material on a section of the barrel and in front of the target, a sample of the powder is introduced into the technological channel of the unit: a given fraction, at a given distance of $800 \mathrm{~mm}$ from the section of the barrel. In particular, in Fig. 8, 9 show graphs for $\mathrm{Al}_{2} \mathrm{O}_{3}$ particles with a fraction of $20 \mu \mathrm{m}$, a sample size of $0.2 \mathrm{~g}$.

Two approaches are used to calculate multiphase flows: the Euler-Lagrange method and the Euler-Euler method. In the concept of homogeneous multiphase Euler modeling, both models - volume fluid model (VOF) and the Euler mixture model - solve the same set of control equations for the mixture (averaged). However, they are based on various physical mechanisms, and therefore they are applied to different multiphase flow regimes. Mixture model designed for two or more phases (fluid or solid particles), which are processed as mutually penetrating continua. The VOF formulation [9] suggests that two fluids (or phases) or more do not mix and do not penetrate each other. Therefore, in any given cell of the control volume, by the fraction of the volumes of local phases, it can be determined whether the cell contains only one of the phases or a mixture of phases.

In Fig. 8, 9, indicating the velocities of the ensemble of particles, particles flying away from the target are shown, since the model did not specify the interaction of particles with the substrate and they ricocheted from the target, and the velocities were determined on the section of the barrel and in front of the target. The picture of the particle velocities before the barrier does not change qualitatively, however, for a given sample of the powder, the numerical values decrease by about $20 \%$. The present effect of a decrease in the particle velocity is quite easily explained when analyzing the distribution of velocity fields and pressures of detonation products. Directly along the axis of the barrel in front of the obstacle, there is an increase in pressure and a drop in velocity, the flow is inhibited, and the particles have to overcome the stagnant zone.

Despite the increasing prevalence of MAF in industry, literary sources have practically no data on the velocity of detonation propagation for MAF-oxygen mixtures. Thus, to verify the model, the calculated data can be compared with experimental values, and additional modeling was performed for acetylene-oxygen mixtures with different ratios of gas components for comparison with the known ones [10].

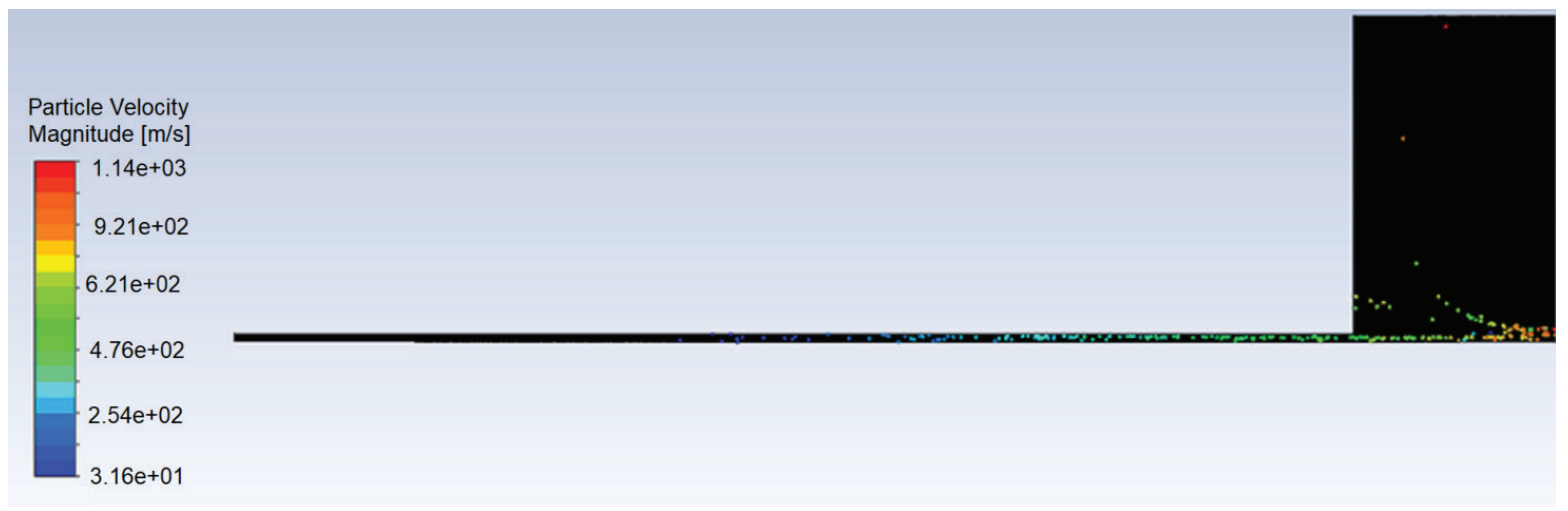

Fig. 8. Distribution of particle velocities along the unit barrel at $t=0.007 \mathrm{~s}$ 


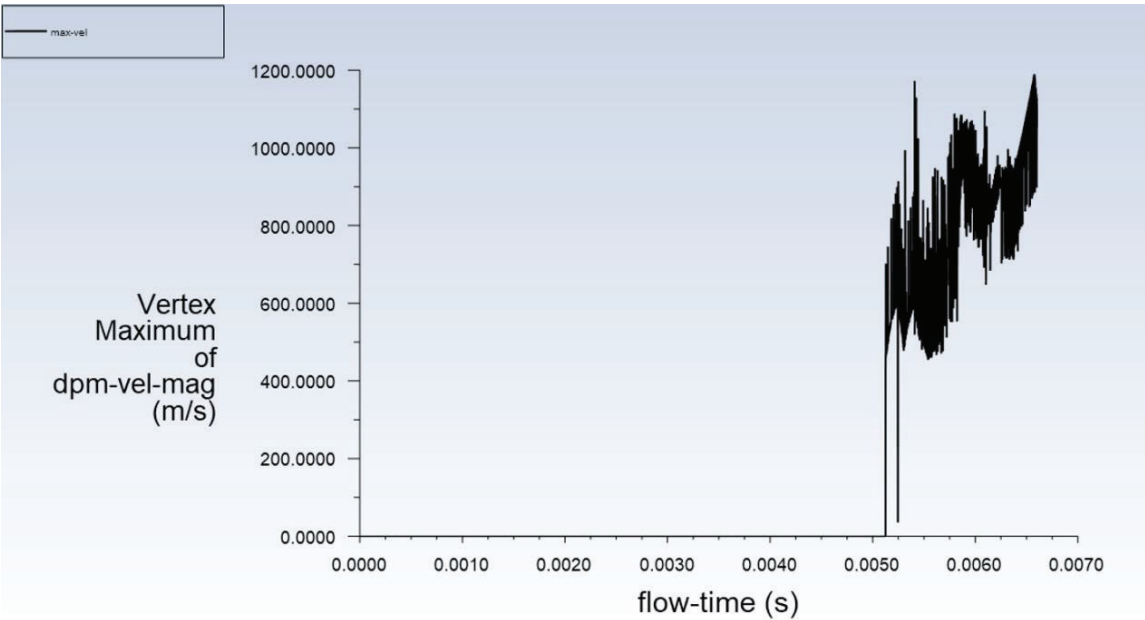

Fig. 9. Velocity distribution of the ensemble of particles at the barrel section

Based on the calculations, the dependences of velocity and temperature on the ratio of the components of the gas mixture are determined (Fig. 10).

To confirm the calculated values of the velocity of propagation of the detonation wave, the following stand scheme was proposed and used (Fig. 11, $a$ ).

At the end of the technological channel of the detonation unit, an additional section with perpendicular branches was installed, in which high-speed photosensors were mounted, which react to the passage of the detonation wave. This allows one to determine the actual velocities from the displacements in the propagation time of the bursts on the first and second channels. Behind the barrel section, the character of the outflow changes,

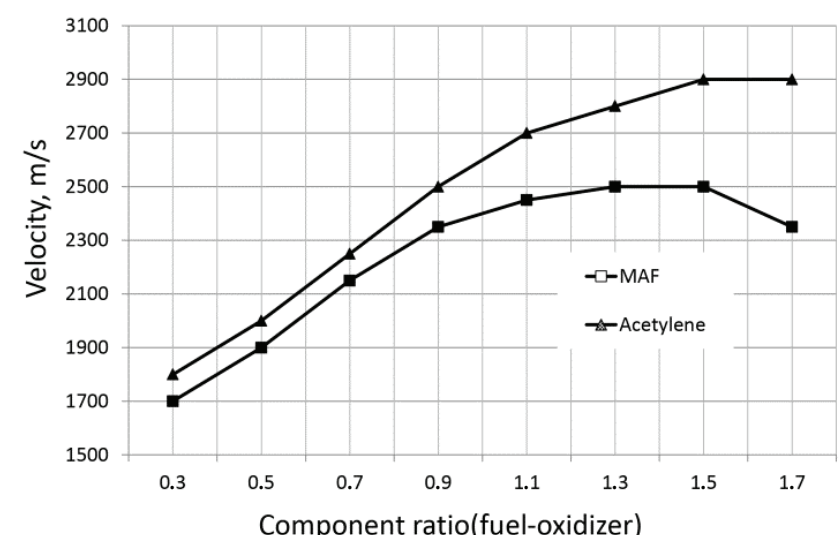

the detonation products expand and the velocity changes. To measure the velocity outside the technological channel, another measurement scheme was used (Fig. 11, b), based on the same principles and elemental base as on the barrel section.

In the case of velocity measurements behind the section, a device is used in which high-speed photosensors can be installed at a distance of $50 \mathrm{~mm}$. Sensors are installed at the lower end at a depth of $60 \mathrm{~mm}$ to reduce the error during the passage of heated particles having luminosity (Fig. 12).

Comparison of the simulation results presented in Fig. 12, with experimental data shows their fairly good agreement (with an error of up to $7 \%$ ).

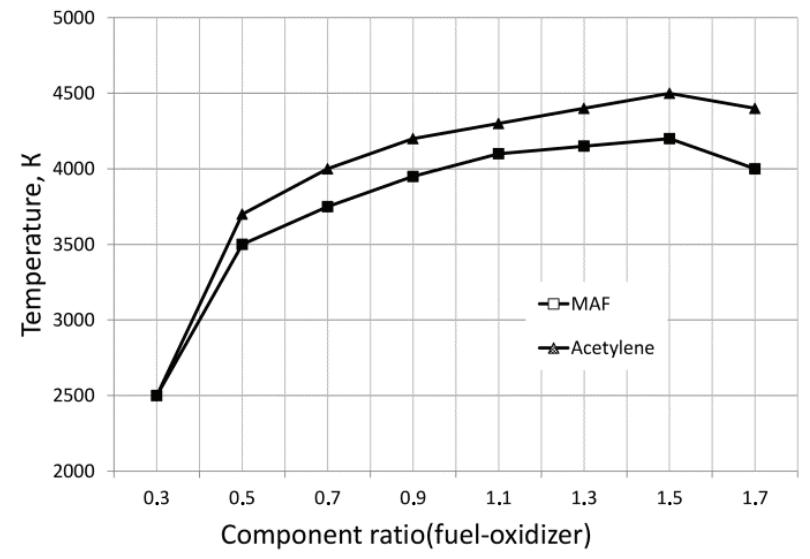

Fig. 10. Dependence of the energy parameters on the ratio of the components of the gas mixture: $a-$ velocity; $b-$ temperature
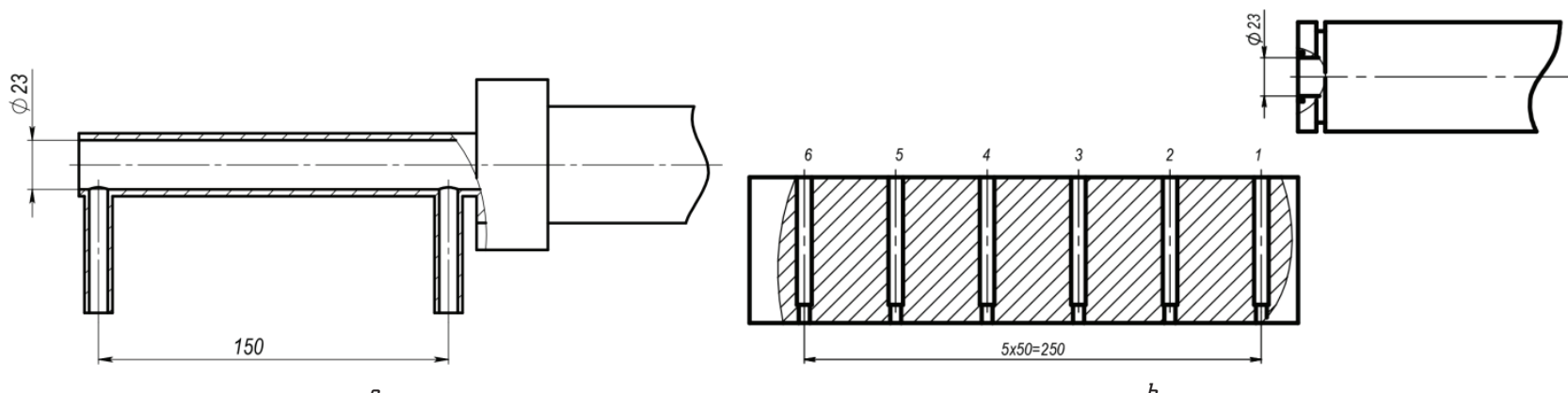

$b$

Fig. 11. The scheme of the measuring stand: $a$ - at the barrel section; $b$ - behind the barrel section 


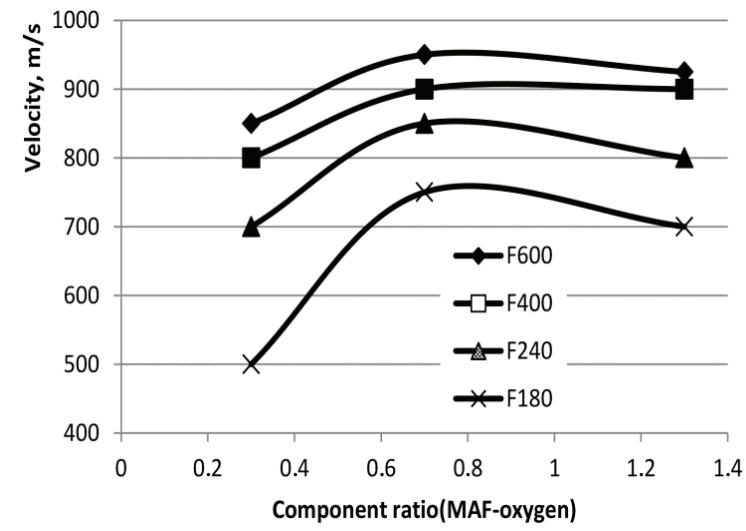

a

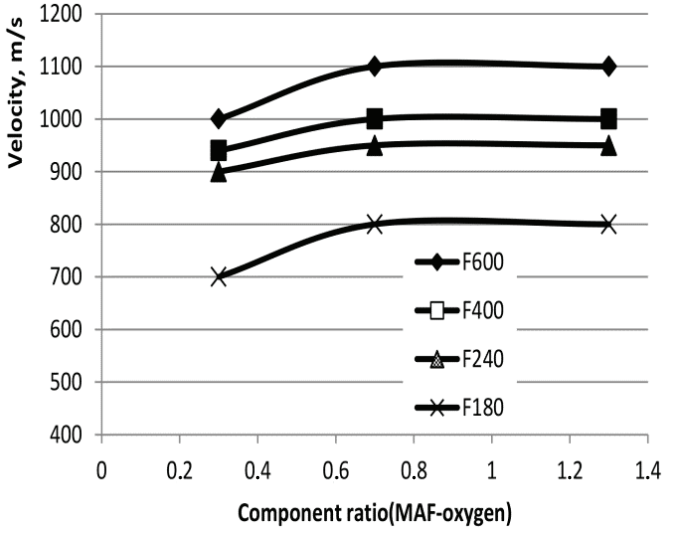

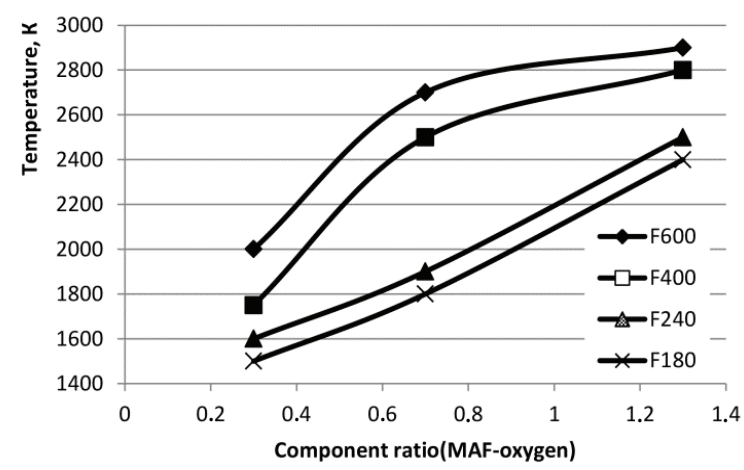

c

Fig. 12. Values of velocity and temperature of $\mathrm{Al}_{2} \mathrm{O}_{3}$ powder particles:

$a$ - velocity at a barrel section; $b$ - velocity in front of the obstacle; $c$ - temperature at a barrel section

\section{Conclusions}

The paper considers the task of modeling the process of acceleration and heating of powder materials by pulsed methods. A mathematical model for numerical modeling is developed and calculations in the ANSYS Fluent environment are carried out. The disadvantages include the large amount of computation characteristic of finite element analysis. However, this drawback is compensated by the possibility of a detailed description of the process of heat transfer and acceleration of the powder material in the process channel without any significant simplifications, which allows to evaluate the real picture of the process. Another advantage of the model is the availability of information on the temperature distribution at any point in the simulated object at any time.

The adequacy of the model used for MAF-oxygen mixtures is estimated, with an error within $7 \%$. The calculation results show that the energy parameters change insignificantly, in comparison with acetylene-oxygen mixtures, the velocity decreases by $400 \mathrm{~m} / \mathrm{s}$, and the drop in the flow temperature is insignificant, no more than 250 degrees and will not have a significant effect on the heating of the powder particles. In addition, the calculated values of velocities up to $1000 \mathrm{~m} / \mathrm{s}$ and temperatures up to $2800 \mathrm{~K}$ allow to speak of sufficiency for the formation of strongly bonded coatings of oxide and carbide ceramics.

The research results will be useful in improving the technology of applying thermal spray coatings by the detonation-gas method.

\section{References}

1. De Souza, V., Neville, A. (2003). Corrosion and erosion damage mechanisms during erosion-corrosion of $\mathrm{WC}-\mathrm{Co}-\mathrm{Cr}$ cermet coatings. Wear, 255 (1-6), 146-156. doi: http://doi.org/10.1016/ s0043-1648(03)00210-2

2. Tucker, R. C. (1995). Plasma Spray, Detonation Gun, and HVOF Deposition Techniques. Materials and Processes for Surface and Interface Engineering, 245-284. doi: http://doi.org/ 10.1007/978-94-011-0077-9_7

3. Yun, A. (2005). Development and Analysis of Advanced Explicit Algebraic Turbulence and Scalar Flux Models for Complex Engineering Configurations. Darmstadt. Available at: https:// tuprints.ulb.tu-darmstadt.de/epda/000579/

4. Spalart, P. R., Deck, S., Shur, M. L., Squires, K. D., Strelets, M. K., Travin, A. (2006). A New Version of Detachededdy Simulation, Resistant to Ambiguous Grid Densities. Theoretical and Computational Fluid Dynamics, 20 (3), 181-195. doi: http://doi.org/10.1007/s00162-006-0015-0

5. Wegner, B., Maltsev, A., Schneider, C., Dreizler, A., Sadiki, A., Janicka, J. (2003). Evaluation of URANS performance in Predicting an Unconfined Swirling Flow with Precessing Vortex core based on LES and Experiments. TSFP3, Sendai, 1, 51-56.

6. Wilcox, D. C. (1994). Turbulence Modeling for CFD. California. Available at: https://www.academia.edu/1160786/Turbulence modeling for CFD

7. Menter, F. (1993). Zonal Two Equation k-w Turbulence Models For Aerodynamic Flows. 23rd Fluid Dynamics, Plasmadynamics, and Lasers Conference. doi: http://doi.org/10.2514/6.1993-2906

8. Metilacetilen-allenovaya frakciya (MAF). Available at: https:// tgko.ru/spravka/gaz/metilacetilen allenovaya frakciya maf/

9. Katopodes, N. D. (2019). Volume of Fluid Method. FreeSurface Flow, 766-802. doi: http://doi.org/10.1016/b978-012-815485-4.00018-8

10. Boguslaev, V. A., Dolmatov, A. I., Zhemaniuk, P. D., Kulagin, A. I. Mikhailutsa, V. G., Simonenko, V. A. (1996). Detonatsionnoe nanesenie pokrytii na detali aviadvigatelei i tekhnologicheskogo osnashcheniia s posleduiushchei magnit-noabrazivnoi obrabotkoi. Zaporozhe: Izd. OAO «Motor Sich», 75-104.

Zorik Ihor, Associate Professor, Department of Technology of Produc tion of Aviation Engines, National Aerospace University H. E. Zhukovsky «Kharkiv Aviation Institute», Ukraine, ORCID: http://orcid.org/ 0000-0003-3053-2369, e-mail: I.Zorik@khai.edu 